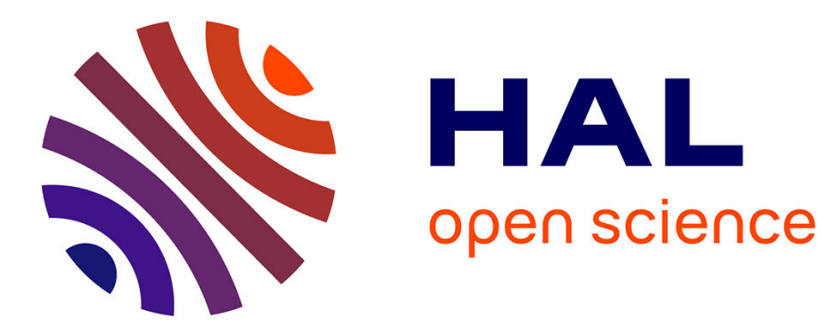

\title{
The impact of young age on breast cancer outcome
}

\author{
L. Livi, I. Meattini, C. Saieva, S. Borghesi, V. Scotti, A. Petrucci, A.
}

Rampini, L. Marrazzo, V. Di Cataldo, S. Bianchi, et al.

\section{To cite this version:}

L. Livi, I. Meattini, C. Saieva, S. Borghesi, V. Scotti, et al.. The impact of young age on breast cancer outcome. EJSO - European Journal of Surgical Oncology, 2010, 36 (7), pp.639. 10.1016/j.ejso.2010.05.016 . hal-00603540

\section{HAL Id: hal-00603540 \\ https://hal.science/hal-00603540}

Submitted on 26 Jun 2011

HAL is a multi-disciplinary open access archive for the deposit and dissemination of scientific research documents, whether they are published or not. The documents may come from teaching and research institutions in France or abroad, or from public or private research centers.
L'archive ouverte pluridisciplinaire HAL, est destinée au dépôt et à la diffusion de documents scientifiques de niveau recherche, publiés ou non, émanant des établissements d'enseignement et de recherche français ou étrangers, des laboratoires publics ou privés. 


\section{Accepted Manuscript}

Title: The impact of young age on breast cancer outcome

Authors: L. Livi, I. Meattini, C. Saieva, S. Borghesi, V. Scotti, A. Petrucci, A. Rampini, L. Marrazzo, V. Di Cataldo, S. Bianchi, L. Cataliotti, G. Biti

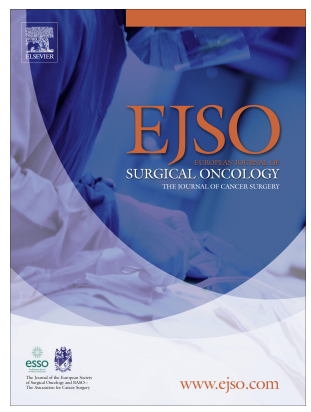

PII:

S0748-7983(10)00124-1

DOI:

10.1016/j.ejso.2010.05.016

Reference: $\quad$ YEJSO 2978

To appear in: European Journal of Surgical Oncology

Received Date: 20 August 2009

Revised Date: 12 April 2010

Accepted Date: 4 May 2010

Please cite this article as: Livi L, Meattini I, Saieva C, Borghesi S, Scotti V, Petrucci A, Rampini A, Marrazzo L, Di Cataldo V, Bianchi S, Cataliotti L, Biti G. The impact of young age on breast cancer outcome, European Journal of Surgical Oncology (2010), doi: 10.1016/j.ejso.2010.05.016

This is a PDF file of an unedited manuscript that has been accepted for publication. As a service to our customers we are providing this early version of the manuscript. The manuscript will undergo copyediting, typesetting, and review of the resulting proof before it is published in its final form. Please note that during the production process errors may be discovered which could affect the content, and all legal disclaimers that apply to the journal pertain. 


\section{THE IMPACT OF YOUNG AGE ON BREAST CANCER OUTCOME}

L. Livi, MD, ${ }^{1}$ I. Meattini, MD, ${ }^{1}$ C. Saieva, MD ${ }^{2}$ S. Borghesi, MD,${ }^{1}$ V. Scotti ${ }^{1}$, A. Petrucci, MD ${ }^{1}$ A. Rampini, MD, ${ }^{1}$ L. Marrazzo, MD, ${ }^{1}$ V. Di Cataldo, ${ }^{1}$ S. Bianchi, MD ${ }^{3}$ L. Cataliotti, MD, ${ }^{4}$ and G. Biti, $\mathrm{MD}^{1}$.

${ }^{1}$ Department of Radiation-Oncology, University of Florence, Florence, Italy

${ }^{2}$ Molecular and Nutritional Epidemiology Unit, ISPO, Cancer Prevention and Research Institute, Florence, Italy

${ }^{3}$ Department of Pathology, University of Florence, Florence, Italy

${ }^{4}$ Department of Surgery, University of Florence, Florence, Italy

Correspondence to:

Icro Meattini, MD

Department of Radiation-Oncology, University of Florence

Viale Morgagni 85, 50134 Florence, Italy

Tel: +39-055-7947719; fax +39-055-4379930

e-mail: icro.meattini@unifi.it

Running Title: breast cancer in young patients

Keywords: breast cancer; young patients; radiation therapy; anthracyclines; mastectomy; breastconserving surgery 


\section{ABSTRACT}

AIMS: we conducted a retrospective analysis in order to evaluate the impact of age on women aged less than 35 years affected by breast cancer.

MATERIALS AND METHODS: between January 1972 and December 2006, 346 patients aged less than 35 years underwent adjuvant treatment at Florence University. The mean age of the patient population was 32 years (range 22-35): 76 patients were under 30 years old, the remaining were above 30 years old.

RESULTS: in our series, 215 patients received adjuvant radiotherapy to whole breast after conservative surgery, 131 patients underwent mastectomy without subsequent radiation therapy and 323 patients had lymphadenectomy. 191 patients received adjuvant chemotherapy, 73 with anthracyclines-containing regimen. With a median time of 2.5 years (range 6 months to 27.6 years) local relapses were observed in 67 cases $(19.4 \%)$. At the multivariate analysis of local disease free survival, ductal and ductal plus lobular histotypes, having more than 3 positive nodes and age emerged as independent significant relapse predictors $(\mathrm{p}=0.018, \mathrm{p}=0.0005, \mathrm{p}=0.003$ and $\mathrm{p}=0.024$, respectively). For the DSS analysis, the median follow-up was 6.8 years (range 0.6-36.7 years). At the multivariate analysis, age $(\mathrm{p}=0.0038)$, positive nodes $(\mathrm{p}=0.0035)$ and distant metastases ( $\mathrm{p}<0.0001)$ resulted to be independent death predictors. Patients younger than 30 had a worse prognosis. At the univariate analysis also local relapse resulted to be statistically significant $(\mathrm{p}=0.0004)$.

CONCLUSIONS: anthracyclines-based chemotherapy seems to improve the outcome of these patients. However there is an urgent need for tailored treatment investigations within the framework of randomized, controlled clinical trials. 


\section{INTRODUCTION}

About $25 \%$ of cases of breast cancer (BC) occur before the menopause, and $15 \%$ of women are diagnosed in the reproductive age group [1-2], with approximately $2 \%$ of cases developing in young women aged 20 to 34 years and $11 \%$ between 35 and 44 [3].

$\mathrm{BC}$ at young age has a more aggressive biological behaviour and is associated with a more unfavourable prognosis compared with the disease arising in older premenopausal patients [4]. Systemic adjuvant therapy with hormonal treatment, chemotherapy, or both are undoubtedly related to the improved rates of mortality from BC noted over the last decade. In a large population-based Canadian study the use of adjuvant systemic therapy was directly related to improved survival rates in women with early BC. Overall survival improved by $10 \%$ for women younger than 50 years of age between 1974 and 1984, and by 4\% for women aged 50 to 89 years between 1980 and 1984 [5].

We conducted a retrospective analysis in order to evaluate the disease specific survival (DSS) and the local disease free survival (LDFS) in a series of young women with BC treated with integrated adjuvant therapeutic modalities.

\section{PATIENTS AND METHODS}

From January 1972 to December 2006, 346 patients aged less than 35 years with BC underwent adjuvant treatment at the Radiotherapy Unit of the University of Florence.

Our series included patients without clinical and radiological evidence of local or distant recurrence after breast surgery at the time of the first evaluation in our Radiotherapy Unit. None of them had prior malignant disease. The mean age of the patient population was 32 years $(\mathrm{SD} \pm 2.90$; range 22-35): 76 patients (22.0\%) were under 30 years old, the remaining were above 30 years old. 


\section{Statistical Analyisis}

The survival time was calculated from the date of surgery to the date of death or the date of the last follow-up for the patients resulted to be alive. In our survival analysis we considered as events the deaths for BC disease (DSS). LDFS was calculated from the date of surgery to the date of local relapse (LR) occurrence. We used the term cumulative incidence to specify the occurrence, as percentage, of local relapse at well-defined follow-up points. Likewise we used the term survival, to specify the percentage of patients still alive, and thus at risk, at well-defined follow-up points. The crude probability of death or LR occurrence was estimated by using the Kaplan-Meier method and differences between patient groups were assessed by the log-rank test. Estimated relative risks of dying or LR occurrence were expressed as hazard ratios (HR) and their corresponding 95\% confidence intervals $(95 \% \mathrm{CI})$. Univariate Cox regression models were used to evaluate the effect of each specific parameter. Multivariate Cox regression models with stepwise selection were performed to identify the major significant death or LR occurrence predictors. All the patients are included in all the analyses. Statistical results were considered significant at a p-value $<0.05$. All statistical tests were performed by the SAS software.

\section{RESULTS}

Patients' characteristics are shown in Table 1. Most cases showed a $\mathrm{pT}_{1}(56 \%)$, a ductal histotype (64.2\%), and none positive lymph node (56.1\%).

According to the protocol followed in our Institute, all patients received radiotherapy (RT) to whole breast only after breast conserving surgery. In our series, 215 patients received adjuvant RT to whole breast, 131 patients underwent mastectomy without subsequent RT and 323 patients had lymphadenectomy $(93.3 \%)$.

The mean RT dose delivered was 50 Gy (range 46-52 Gy), in 2 Gy daily fractions. A dose boost on the tumour bed was administered by electrons. At the discretion of the radiation oncologist 
the total boost dose ( 2 Gy daily fraction) ranged between 6 and 10 Gy for patients with negative surgical margins and between 14 and 16 Gy for patients with positive margins.

One hundred and ninety-one patients received adjuvant chemotherapy (CT), that consisted of 6 courses of iv CMF 1-8,28 (cyclophosphamide $600 \mathrm{mg} / \mathrm{m}^{2}$, methotrexate $40 \mathrm{mg} / \mathrm{m}^{2}$ and 5 fluorouracil $600 \mathrm{mg} / \mathrm{m}^{2}$ ) for 98 patients; 4 courses of epirubicin (100 mg/m 2 every 21 days) followed by 4 cycles of iv CMF for 43 women; 4 courses of AC 1,21 (doxorubicin $60 \mathrm{mg} / \mathrm{m}^{2}$ and cyclophosphamide $\left.600 \mathrm{mg} / \mathrm{m}^{2}\right)$ for 11 patients; 4 AC followed by 4 cycles of paclitaxel $1,21(175$ $\mathrm{mg} / \mathrm{m}^{2}$ ) for 19 cases, and other schedules in 20 patients.

Adjuvant hormonal treatment was prescribed for 74 patients, 22 of them received Tamoxifen, and 52 Tamoxifen associated with GnRH agonist. Ten patients were treated with bilateral oophorectomy.

With a median time of 2.5 years (range 6 months to 27.6 years) LR were observed in 67 cases $(19.4 \%)$. Twenty patient had supraclavicular fossa relapse (5.8\%), 14 developed single chest wall relapse (4.0\%), 13 had multiple chest wall relapse (3.8\%), 10 had multicentric relapse (2.9\%), 7 developed internal mammary nodal chain relapse $(2.0 \%)$ and three patients had axillary relapse $(0.9 \%)$

At the univariate regression analysis for LDFS (Table 2), histotype and positive axillary lymph nodes emerged as significant LR occurrence predictors ( $\mathrm{p}=0.0002$ and $\mathrm{p}=0.0008$ respectively). Particularly, the lobular and the ductal plus lobular histotypes showed a significant increased risk of LR in comparison to the ductal histotype ( $\mathrm{p}=0.02$ and $\mathrm{p}<0.0001$, respectively). Patients with a number of positive axillary lymph nodes greater than 3 showed an almost three-fold increase in risk of LR when compared with patients with negative axillary lymph nodes $(\mathrm{p}=0.0004)$. CT did not emerge as a significant relapse predictor $(\mathrm{p}=0.66)$, although a protective effect was found. Even though not statistically significant $(\mathrm{p}=0.068)$ age was shown to have some effect. At the multivariate analysis with stepwise regression lobular and ductal plus lobular histotypes, 
positive nodes $>3$ and age emerged as independent significant relapse predictors $(\mathrm{p}=0.018$, $\mathrm{p}=0.0005, \mathrm{p}=0.003$ and $\mathrm{p}=0.024$ respectively).

After a median time of 2.6 years (range 0.5-22.7 years), distant metastases occurred in 120 patients $(34.7 \%)$.

For the DSS analysis, the median follow-up period was 6.78 years (range 0.6-36.7 years). At the time of the present analysis 215 patients $(62.1 \%)$ were still alive. At the regression univariate analysis age $(\mathrm{p}<0.0001)$, pathological tumour size $(\mathrm{p}<0.0001)$, histotype $(\mathrm{p}=0.028)$, positive nodes $(\mathrm{p}<0.0001), \mathrm{CT}(\mathrm{p}=0.0001), \mathrm{LR}(\mathrm{p}=0.0004)$ and distant metastases $(\mathrm{p}<0.0001)$ all emerged as significant death predictors, as shown in Table 3. Surgical treatment (mastectomy versus breast conservation) did not turn out to be a significant LR predictor at the statistical analysis (data not shown).

In the subgroup of patients with positive axillary lymph nodes we evaluated whether a different regimen of CT influenced DSS.

We found that there was not a significant statistical difference in DSS between CMF and anthracyclines $(\mathrm{p}=0.71)$ although anthracyclines showed a better DSS (40\% versus $21 \%)$. At the multivariate analysis with stepwise regression performed on the whole series, age $(\mathrm{p}=0.0038)$, positive nodes $(\mathrm{p}=0.0035)$ and distant metastases $(\mathrm{p}<0.0001)$ resulted to be independent death predictors. DSS curves of the whole series by number of positives lymph-nodes and age groups (age $\leq 30$ versus 30-35 years) are shown in Figure 1 and 2.

We analyzed whether survival rates have changed over the 30 year time span of the study, by splitting the whole period in four intervals (before 1980, 1981-1990, 1991-2000, after 2000). As expected, a statistically significant improvement in terms of overall survival emerged in recent years $(p=0.008)$, but no effect is observed on the results of the multivariate analysis. 


\section{DISCUSSION}

Survival following BC is improving, with over $88 \%$ of patients alive at 5 years [6] although the prognosis appears to be worse in young women under 35 years at diagnosis [7]. In our series of BC cases younger than 35 years at diagnosis, age younger than 30 years, positive nodes and distant metastases lead to a worse outcome in terms of DSS. In particular, age lower than 30 and positive nodes resulted to be independent prognostic factors at multivariate analysis for LDFS.

Similarly, Henderson reported lymph node involvement in BC to be the dominant prognostic indicator for later systemic disease [8]. Concerning age, Bernstein et al found that, if the HR of 1.0 describes the risk for women aged 40 to 49 , then it is 1.8 for women under 30 years, 1.7 for those 30 to 34 years, and 1.5 for those 35 to 39 years [9].

The observed difference in prognosis may relate to differences in the biology of $\mathrm{BC}$ in younger women. In our study, as in other reported series, the majority of BCs presenting in young women are invasive cancers and most are ductal infiltrating. Younger women are more likely to show larger tumours [10]. Moreover it is now recognized that 'triple negative' (ER-ve, PR-ve and HER2-ve) and basal-like BCs, more common in younger women, have an aggressive clinical behaviour and are more likely to relapse within the first 5 years [11].

In our series, patients younger than 30 years with positive nodes and specific histotypes (lobular or ductal plus lobular) had an higher rate of LR occurrence. Vicini et al. suggested that young patients have a significantly greater risk of local recurrence that is independent of other previously defined risk factors [12] .

In our study patients who underwent adjuvant CT had a better outcome in terms of LDFS at univariate analysis although with no significant results. Although the results of our study should be interpreted cautiously due to the paucity of the population and the lack of a randomized design, they suggest that, in this subset of patients, anthracycline-based CT reduced disease relapse. 
Adjuvant CT is known to decrease the LR and to improve the survival rate of women with node-positive BC [13]. In women under 50 years old, the mean absolute improvement in 10-year survival after adjuvant chemotherapy is $7-11 \%$ [14].

It has been demonstrated that 4 courses of $\mathrm{AC}$ are equivalent to 6 courses of CMF [15]. However, it is known that anthracycline-containing regimens yield superior results, in terms of both recurrence-free survival and OS, either in node-positive or in node-negative BC patients [1617]. Similarly, our results showed a lower risk of LR in patients who underwent anthracyclinebased CT. A recent meta-analysis reported that in young women (under 50 years old), 6 cycles of an anthracycline-based combination CT (e.g. with FEC or FAC) are associated with a reduction in mortality of about $38 \%$ which approximates to a $5-15 \%$ absolute improvement in survival at 15 years of follow-up [18].

It was suggested that CMF might not be enough to treat very young premenopausal patients [19]. The anthracyclines and taxanes are considered the most effective drugs in the adjuvant setting and CMF is currently given to young patients in only few selected occasions. In our series the difference in DSS between CMF and anthracyclines was not statistically significant, most probably due to a small number of patients receiving CT. At least two randomised trials showed that 4 cycles of AC followed by paclitaxel improved OS compared with $\mathrm{AC}$ alone in patients with node-positive BC [20-21].

Endocrine treatment effects had been considered of secondary importance for younger women presenting with a node-positive BC. However, the value of chemo-endocrine therapy for pre-menopausal patients has been defined recently. Meta-analysis of multiple randomized trials confirms that combining anthracyclines-based CT with 5 years of Tamoxifen, in women with $\mathrm{HR}+\mathrm{ve}$ disease, reduces the risk of dying from $\mathrm{BC}$ by about 57\% [22]. The International Breast Cancer Study Group Trial 13-93 results showed that Tamoxifen after adjuvant CT significantly improved treatment outcome in premenopausal patients with endocrine-responsive disease (HR for Tamoxifen $v s$ no Tamoxifen 0.59; p <0.0001) [23]. 
The impact of LR on survival is still a debated topic. Our data show that LR decreases breast cancer specific survival, but only in the univariate analysis $(\mathrm{p}=0.0004)$. In our Institute, all patients received RT to whole breast only after breast-conserving surgery. According to a recent paper [24], the local disease control does not uniformly improve survival; the largest absolute reduction in 5year LR probability after post-mastectomy RT was seen for the poor prognosis group ( $>3$ positive nodes, tumor size $>5 \mathrm{~cm}$, Grade 3 ), but this large LR reduction did not translate into any reduction in 15-year BC mortality.

\section{CONCLUSIONS}

Young age, number of positive lymph nodes and distant metastases are associated with a worse DSS. LR resulted a statistically significant parameter at DSS univariate analysis. Patients younger than 30 years at the diagnosis of $\mathrm{BC}$ with more than 3 positive axillary lymph nodes and specific histotypes resulted to be associated to an increased risk of LR.

There is an urgent need for tailored treatment investigations with anthracyclines-based CT regimens, and young women with BC should be considered the optimal candidates for a combined anti-cancer strategy within the framework of randomized, controlled clinical trials. 


\section{REFERENCES}

1) Jemal A, Siegel R, Ward E, et al. Cancer statistics. CA Cancer J Clin 2006; 56:106-30.

2) Zekri JM, El-Helw LM, Purohit OP, et al. Epirubicin/Vinorelbine adjuvant chemotherapy in young women with breast cancer is associated with preservation of menstrual function. Clinical Oncology 2008; 20:513-6.

3) Ries L, Melbert D, Krapcho M, et al. SEER Cancer Statistics Review, 1975-2005. Natl Cancer Inst 2008 .

4) Hickey M, Peate M, Saunders CM, et al. Breast cancer in young women and its impact on reproductive function. Hum Reprod Update 2009; 15:323-39.

5) Olivotto IA, Bajdik CD, Plenderleith IH, et al. Adjuvant systemic therapy and survival after breast cancer. N Engl J Med 1994; 330:805.

6) Pagani O, Goldhirsch A. Breast cancer in young women: climbing for progress in care and knowledge. Women's Health 2006; 2:717-32.

7) Aebi S, Gelber S, Castiglione-Gertsch M, et al. Is chemotherapy alone adequate for young women with oestrogen-receptor-positive breast cancer? Lancet 2000; 355:1869-74.

8) Henderson IC, Patek AJ. The relationship between prognostic and predictive factors in the management of breast cancer. Breast Cancer Res Treat 1998; 52:261.

9) Bernstein V, et al. How young is too young? The impact of age on premenopausal breast cancer prognosis. Breast Cancer Res Treat 2002; 76:A137.

10) Anders CK, Hsu DS, Broadwater G, et al. Young age at diagnosis correlates with worse prognosis and defines a subset of breast cancers with shared patterns of gene expression. J Clin Oncol 2008; 26:3324-30.

11) Rakha EA, Reis-Filho JS, Ellis IO. Basal-like breast cancer: a critical review. J Clin Oncol $2008 ; 26: 2568-81$.

12) Vicini FA, Kestin LL, Goldstein NS, et al. Impact of young age on outcome in patients with ductal carcinoma-in-situ treated with breast-conserving therapy. J Clin Oncol 2000; 18:296-306. 
13) Early Breast Cancer Trialists' Collaborative Group. Systemic treatment of early breast cancer by hormonal, cytotoxic or immune therapy: 133 randomized trials involving 31,000 recurrences and 24,000 deaths among 75,000 women. Lancet 1992; 339:71-85.

14) Early Breast Cancer Trialists' Collaborative Group. Polychemotherapy for early breast cancer: an overview of the randomised trials. Lancet 1998; 19:930-42.

15) Fisher B, Brown AM, Dimitrov NV, et al. Two months of doxorubicin-cyclophosphamide with and without interval reinduction therapy compared with 6 months of cyclophosphamide, methotrexate, and fluorouracil in positive-node breast cancer patients with tamoxifen-nonresponsive tumors: results from the National Surgical Adjuvant Breast and Bowel Project B-15. J Clin Oncol 1990; 8:1483-96.

16) Levine $\mathrm{MN}$, Bramwell $\mathrm{VH}$, Pritchard $\mathrm{KI}$, et al. Randomized trial of intensive cyclophosphamide, epirubicin, and fluorouracil chemotherapy compared with cyclophosphamide, methotrexate, and fluorouracil in premenopausal women with node-positive breast cancer. National Cancer Institute of Canada Clinical Trials Group. J Clin Oncol 1998; 16:2651-8.

17) Hutchins LF, Green SJ, Ravdin PM, et al. Randomized, controlled trial of cyclophosphamide, methotrexate, and fluorouracil versus cyclophosphamide, doxorubicin, and fluorouracil with and without tamoxifen for high-risk, node-negative breast cancer: treatment results of Intergroup Protocol INT-0102. J Clin Oncol 2005; 23:8313-21.

18) Early Breast Cancer Trialists' Collaborative Group, Clarke M, Coates AS, et al. Adjuvant chemotherapy in oestrogen-receptor-poor breast cancer: patient-level meta-analysis of randomised trials. Lancet 2008; 371:29-40.

19) Papaldo P, Di Cosimo S, Ferretti G, et al. Is anthracycline-based chemotherapy alone adequate for young women with estrogen receptor-positive breast cancer? The Breast 2006; 15:269-72.

20) Henderson IC, Berry DA, Demetri GD, et al. Improved outcome from adding sequential paclitaxel but not escalating doxorubicin dose in an adjuvant chemotherapy regimen for patients with node positive primary breast cancer. J Clin Oncol 2003; 21:976-83. 
21) Sparano JA, Wang M, Martino S, et al. Weekly paclitaxel in the adjuvant treatment of breast cancer. N Engl J Med 2008; 358:1663-71.

22) Early Breast Cancer Trialists' Collaborative Group. Effects of chemotherapy and hormonal therapy for early breast cancer on recurrence and 15-year survival: an overview of the randomised trials. Lancet 2005; 365:1687-717.

23) International Breast Cancer Study Group. Tamoxifen after adjuvant chemotherapy for premenopausal women with lymph node-positive breast cancer: International Breast Cancer Study Group Trial 13-93. J Clin Oncol 2006; 24:1332-41.

24) Kyndi M, Overgaard M, Nielsen HM, et al. High local recurrence risk is not associated with large survival reduction after postmastectomy radiotherapy in high-risk breast cancer: a subgroup analysis of DBCG 82 b\&c. Radiother Oncol 2009; 90:74-9. 
Table 1. Distribution of 346 breast cancer according to selected individual characteristics.

\begin{tabular}{|l|c|c|}
\multicolumn{1}{c}{ Variable } & N \\
\hline Age (years) & 76 & 22.0 \\
$\leq 30$ & 270 & 78.0 \\
\hline$>30$ and <35 & & \\
\hline Surgical treatment & 131 & 37.9 \\
Mastectomy & 215 & 62.1 \\
Breast conservation & 323 & 93.3 \\
Lymphadenectomy & & \\
\hline pT & 49 & 14.2 \\
1a-1b & 110 & 31.8 \\
1c & 148 & 42.8 \\
2 & 23 & 6.6 \\
3 & 16 & 4.6 \\
4 & & \\
\hline Histotype & 222 & 64.2 \\
Ductal & 31 & 9.0 \\
Lobular & 37 & 10.7 \\
Ductal plus Lobular & 56 & 16.1 \\
\hline Other & & \\
\hline Positive lymph nodes & 194 & 56.1 \\
0 & 90 & 26.0 \\
1-3 & 62 & 17.9 \\
\hline$>3$ & & \\
\hline Oestrogen receptor & 79 & 22.8 \\
Negative & 113 & 32.7 \\
Positive & 154 & 44.5 \\
\hline$N A$ & & \\
\hline Progesterone receptor & 81 & 23.4 \\
Negative & 110 & 31.8 \\
Positive & 155 & 44.8 \\
\hline$N A$ & 346 & 100.0 \\
\hline Total & & \\
\hline & & \\
\hline
\end{tabular}

NA: not available 
Table 2. Local Disease Free Survival analysis* of 346 breast cancer cases according to selected individual characteristics: number of patients at risk, number of relapses, cumulative incidence (C.I.), log rank test and Hazard Risk (HR) with 95\% Confidence Interval (Univariate regression analysis).

Variable

$\begin{array}{ccccc}\begin{array}{c}\text { Patients } \\ \text { at risk }\end{array} & \begin{array}{c}\text { Relapses } \\ (\mathrm{n})\end{array} & \begin{array}{c}\text { C.I. } \\ (\%)\end{array} & \begin{array}{c}\text { log rank } \\ \text { test }\end{array} & \begin{array}{c}\text { HR } \\ (95 \% \mathrm{CI})\end{array}\end{array}$

(n)

\begin{tabular}{|c|c|c|c|c|c|}
\hline $\begin{array}{l}\text { Age (years) } \\
\leq 30 \\
>30 \text { and }<35\end{array}$ & $\begin{array}{c}76 \\
270\end{array}$ & $\begin{array}{l}18 \\
49\end{array}$ & $\begin{array}{l}40 \\
32\end{array}$ & 0.068 & - \\
\hline $\begin{array}{l}\text { pT } \\
1 \mathrm{a}-1 \mathrm{~b} \\
1 \mathrm{c} \\
2 \\
3 \\
4\end{array}$ & $\begin{array}{c}49 \\
110 \\
148 \\
23 \\
16\end{array}$ & $\begin{array}{c}7 \\
18 \\
34 \\
5 \\
3\end{array}$ & $\begin{array}{l}23 \\
35 \\
30 \\
28 \\
35\end{array}$ & 0.64 & - \\
\hline $\begin{array}{l}\text { Histotype } \\
\text { Ductal } \\
\text { Lobular } \\
\text { Ductal plus Lobular } \\
\text { Other } \\
\end{array}$ & $\begin{array}{l}222 \\
31 \\
37 \\
56 \\
\end{array}$ & $\begin{array}{c}33 \\
9 \\
13 \\
12 \\
\end{array}$ & $\begin{array}{l}21 \\
31 \\
60 \\
38\end{array}$ & 0.0002 & $\begin{array}{c}1^{\wedge} \\
2.37(1.13-4.95) \\
3.79(1.98-7.26) \\
1.42(0.73-2.75) \\
\end{array}$ \\
\hline $\begin{array}{l}\text { Pos. lymph nodes } \\
0 \\
1-3 \\
>3\end{array}$ & $\begin{array}{c}194 \\
90 \\
62\end{array}$ & $\begin{array}{l}34 \\
16 \\
17\end{array}$ & $\begin{array}{l}33 \\
26 \\
40\end{array}$ & 0.0008 & $\begin{array}{c}1^{\wedge} \\
1.16(0.64-2.10) \\
2.93(1.62-5.30)\end{array}$ \\
\hline $\begin{array}{l}\text { Chemotherapy } \\
\text { No } \\
\text { EPI+CMF } \\
\text { CMF } \\
\text { AC } \\
\text { EPI+TAX } \\
\text { Other regimens }\end{array}$ & $\begin{array}{l}155 \\
43 \\
98 \\
11 \\
19 \\
20\end{array}$ & $\begin{array}{c}37 \\
6 \\
21 \\
- \\
1 \\
2\end{array}$ & $\begin{array}{c}36 \\
17 \\
30 \\
- \\
6 \\
11\end{array}$ & 0.66 & 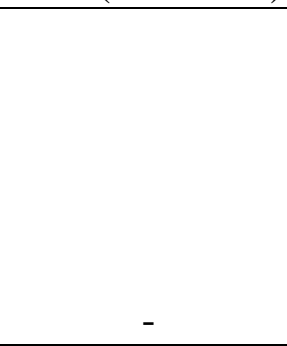 \\
\hline
\end{tabular}

$1^{\wedge}=$ reference category for univariate regression analysis.

* The multivariate regression analysis included all parameters listed in the table 2 (age, pT, histotype, number of positive lymph nodes, chemotherapy). Only four parameters emerged as independent significant relapse predictors at stepwise selection (age: HR: 0.53, 95\% CI 0.31-0.92, $\mathrm{p}=0.024$; lobular histotype:

HR: 2.38, 95\%CI 1.16-4.90, $\mathrm{p}=0.018$; lobular+ductal histotype : HR: $3.18,95 \%$ CI 1.66-6.08, $\mathrm{p}=0.0005$; positive lymph nodes >3: HR: 2.39, 95\%CI 1.33-4.27, $\mathrm{p}=0.008$ ). 
Table 3. Disease specific survival* of 346 breast cancer cases according to selected individual characteristics: number of patients at risk, number of deaths, survival, log rank test and Hazard Risk with 95\% Confidence Interval (Univariate regression analysis).

Variable

$\begin{array}{ccccc}\text { Patients } & \begin{array}{c}\text { Deaths } \\ \text { at risk }\end{array} & \begin{array}{c}\text { Survival } \\ (\mathrm{n})\end{array} & \begin{array}{c}\text { log rank } \\ \text { test }\end{array} & \begin{array}{c}\text { HR } \\ (95 \% \mathrm{CI})\end{array}\end{array}$

(n)

\begin{tabular}{|c|c|c|c|c|c|}
\hline $\begin{array}{l}\text { Age (years) } \\
\leq 30 \\
>30 \text { and }<35\end{array}$ & $\begin{array}{c}76 \\
270 \\
\end{array}$ & $\begin{array}{l}39 \\
92\end{array}$ & $\begin{array}{l}33.2 \\
50.5\end{array}$ & $<0.0001$ & $\begin{array}{c}1^{\wedge} \\
0.48(0.33-0.69)\end{array}$ \\
\hline $\begin{array}{l}\mathbf{p T} \\
1 \mathrm{a}-1 \mathrm{~b} \\
1 \mathrm{c} \\
2 \\
3 \\
4 \\
\end{array}$ & $\begin{array}{c}49 \\
110 \\
148 \\
23 \\
16\end{array}$ & $\begin{array}{l}10 \\
20 \\
76 \\
13 \\
12\end{array}$ & $\begin{array}{l}65.6 \\
66.6 \\
39.5 \\
36.0 \\
14.6\end{array}$ & $<0.0001$ & $\begin{array}{l}1^{\wedge} \\
0.78(0.37-1.67) \\
2.13(1.10-4.13) \\
2.73(1.20-6.23) \\
4.54(1.96-10.5)\end{array}$ \\
\hline $\begin{array}{l}\text { Histotype } \\
\text { Ductal } \\
\text { Lobular } \\
\text { Ductal plus Lobular } \\
\text { Other } \\
\end{array}$ & $\begin{array}{c}222 \\
31 \\
37 \\
56 \\
\end{array}$ & $\begin{array}{l}83 \\
15 \\
17 \\
16\end{array}$ & $\begin{array}{l}50.4 \\
25.5 \\
18.5 \\
54.1 \\
\end{array}$ & 0.028 & $\begin{array}{c}1^{\wedge} \\
1.46(0.84-2.53) \\
1.84(1.09-3.12) \\
0.74(0.44-1.27) \\
\end{array}$ \\
\hline $\begin{array}{l}\text { Pos. lymph nodes } \\
0 \\
1-3 \\
>3 \\
\end{array}$ & $\begin{array}{c}194 \\
90 \\
62\end{array}$ & $\begin{array}{l}44 \\
45 \\
42\end{array}$ & $\begin{array}{c}68.7 \\
30.1 \\
8.2\end{array}$ & $<0.0001$ & $\begin{array}{c}1^{\wedge} \\
2.57(1.69-3.89) \\
6.05(3.92-9.30)\end{array}$ \\
\hline $\begin{array}{l}\text { Chemotherapy } \\
\text { No } \\
\text { EPI+CMF } \\
\text { CMF } \\
\text { AC } \\
\text { EPI+TAX } \\
\text { Other regimens } \\
\end{array}$ & $\begin{array}{l}155 \\
43 \\
98 \\
11 \\
19 \\
20 \\
\end{array}$ & $\begin{array}{c}52 \\
15 \\
43 \\
- \\
6 \\
15\end{array}$ & $\begin{array}{c}60.6 \\
45.8 \\
20.1 \\
- \\
51.2 \\
16.8 \\
\end{array}$ & $<0.0001$ & $\begin{array}{c}1^{\wedge} \\
1.84(1.02-3.19) \\
1.68(1.12-2.52) \\
- \\
2.16(1.13-6.27) \\
3.67(1.06-6.54) \\
\end{array}$ \\
\hline $\begin{array}{l}\text { Local relapses } \\
\text { No } \\
\text { Yes }\end{array}$ & $\begin{array}{r}279 \\
67\end{array}$ & $\begin{array}{l}87 \\
44\end{array}$ & $\begin{array}{l}55.8 \\
20.1 \\
\end{array}$ & 0.0004 & $\begin{array}{c}1^{\wedge} \\
1.90(1.32-2.73)\end{array}$ \\
\hline $\begin{array}{l}\text { Distant Metastases } \\
\text { No } \\
\text { Yes }\end{array}$ & $\begin{array}{l}226 \\
120\end{array}$ & $\begin{array}{c}13 \\
118\end{array}$ & $\begin{array}{c}91.6 \\
0.9\end{array}$ & $<0.0001$ & $\begin{array}{c}1^{\wedge} \\
33.8(18.8-60.8)\end{array}$ \\
\hline
\end{tabular}

$1^{\wedge}=$ reference category for univariate regression analysis

*The multivariate regression analysis included all parameters listed in the table 3 (age, pT, histotype, number of positive lymph nodes, chemotherapy, local relapses, distant metastases). Only three parameters emerged as independent significant death predictors at stepwise selection (age: HR: 0.57, 95\%CI 0.39-0.83, $\mathrm{p}=0.0038$; positive lymph nodes: HR: 1.42 , 95\%CI 1.12-1.79, $\mathrm{p}=0.0035$; distant metastases: HR: 26.98, 95\% CI 14.75-49.34, $\mathrm{p}<0.0001)$. 
Figure 1. DSS curves of 346 breast cancer cases by number of lymph-nodes positives.

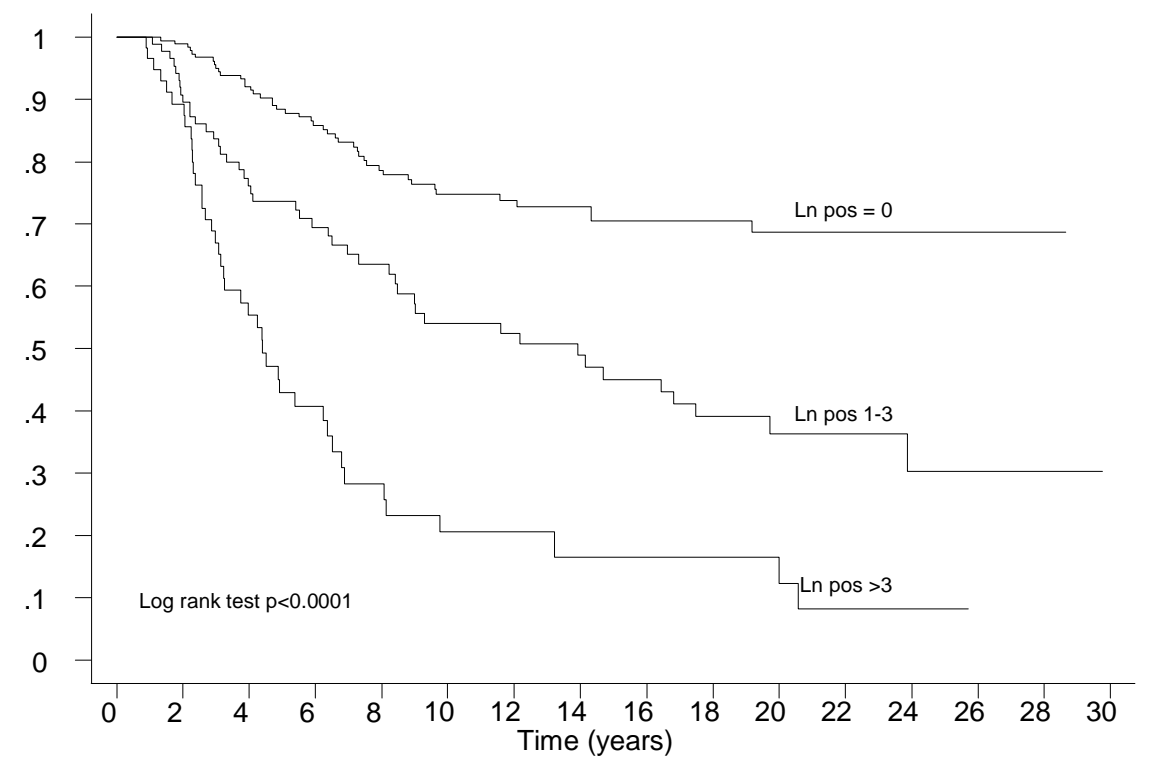

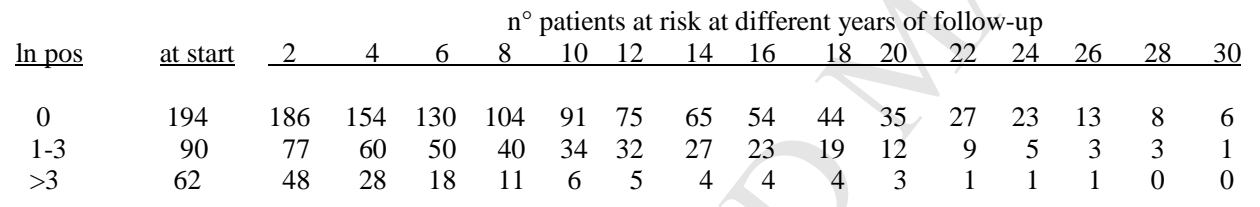


Figure 2. DSS curves of 346 breast cancer cases by age groups

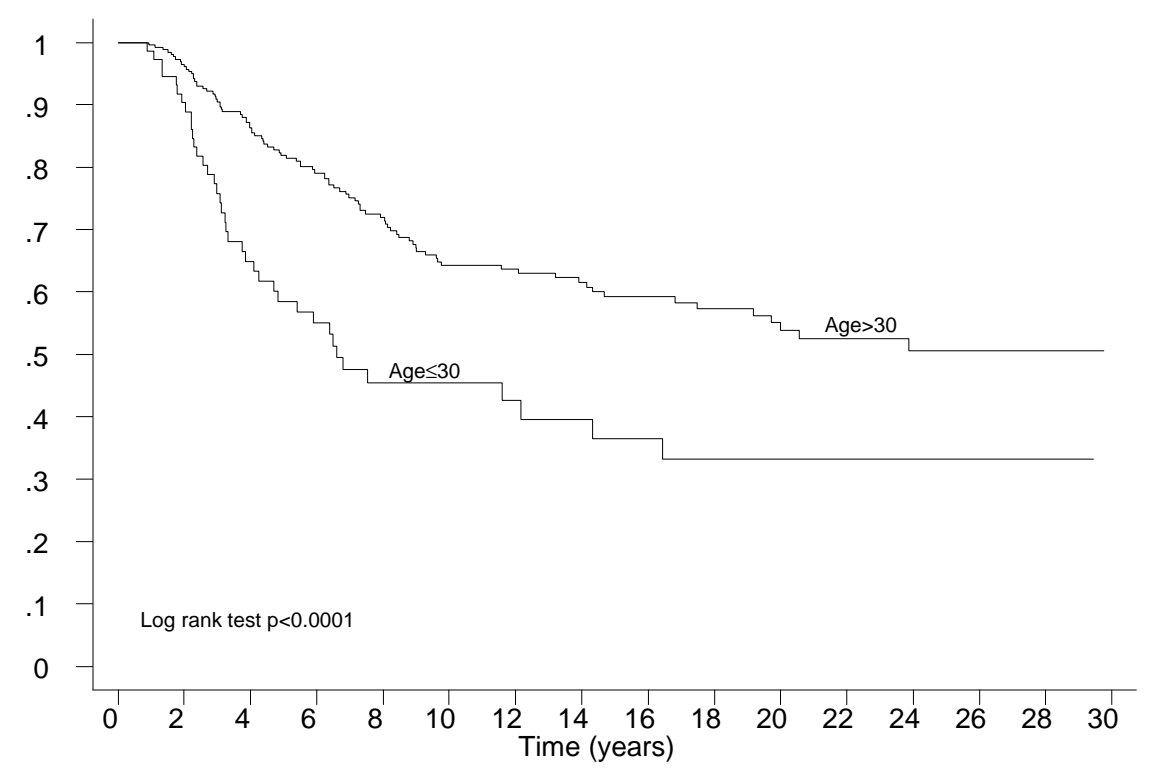

\begin{tabular}{|c|c|c|c|c|c|c|c|c|c|c|c|c|c|c|c|}
\hline & & & & & ${ }^{\circ}$ patier & ts at & sk at & diffe & nt ye & ars 0 & ollo & & & & \\
\hline at start & 2 & 4 & 6 & 8 & 10 & 12 & 14 & 16 & 18 & 20 & 22 & 24 & 26 & 28 & 30 \\
\hline 76 & 64 & 41 & 32 & 21 & 20 & 15 & 13 & 11 & 9 & 6 & 5 & 4 & 3 & 1 & 0 \\
\hline 270 & 247 & 201 & 166 & 134 & 112 & 97 & 83 & 70 & 58 & 44 & 33 & 26 & 13 & 10 & 7 \\
\hline
\end{tabular}


Figure 3. DSS curves of 346 breast cancer cases by study period.

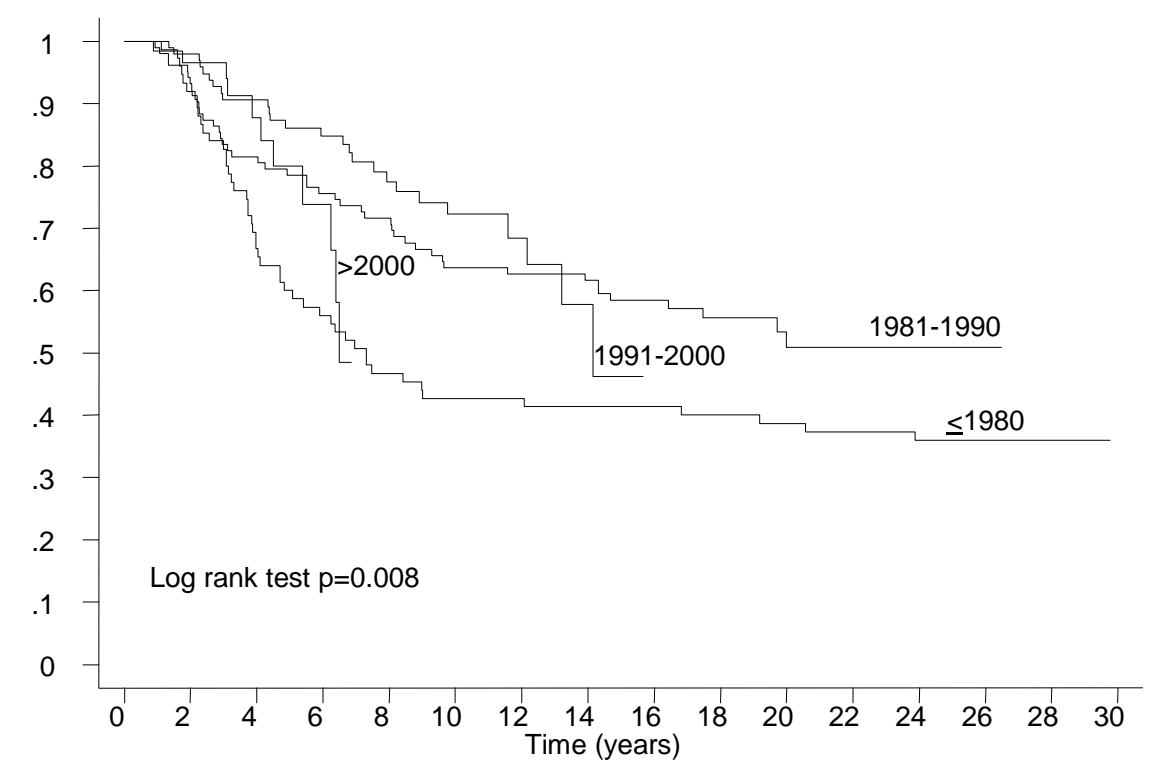

$\mathrm{n}^{\circ}$ patients at risk at different years of follow-up

\begin{tabular}{|c|c|c|c|c|c|c|c|c|c|c|c|c|c|c|c|c|c|}
\hline period & $\underline{\text { at start }}$ & 2 & 4 & 6 & 8 & 10 & 12 & 14 & 16 & 18 & 20 & 22 & 24 & 26 & 28 & 30 & $\%$ DSS \\
\hline$\leq 1980$ & 76 & 69 & 50 & 42 & 35 & 32 & 32 & 31 & & 30 & 29 & 28 & 25 & 15 & 11 & 7 & 35.9 \\
\hline 1981-1990 & 103 & 96 & 83 & 76 & 72 & 64 & 63 & & & 37 & 21 & 10 & 5 & 1 & 0 & - & 50.9 \\
\hline $1991-2000$ & 98 & 95 & 84 & 69 & 48 & 35 & & & & - & - & - & - & - & - & - & 46.2 \\
\hline$>2000$ & 69 & 51 & 24 & 11 & - & & & - & - & - & - & - & - & - & - & - & 48.5 \\
\hline
\end{tabular}

